F. Reprod. Fert. (1971) 27, 159-165

\title{
THE EFFECT OF X-RAYS ON LIPIDS, PHOSPHOLIPIDS AND CHOLESTEROL OF THE MOUSE TESTIS
}

\author{
NIRMAL K. KOGHAR AND R. G. HARRISON \\ Department of Anatomy, The University of Liverpool, \\ Liverpool
}

(Received 30th Fanuary 1970)

\begin{abstract}
Summary. The testes of mature male $A_{2} G$ mice were exposed to a single dose of $1000 r$ of X-rays, and examined at varying intervals up to 146 days after irradiation. Lipids, phospholipids and cholesterol were studied in the control and irradiated mice using histochemical techniques, and estimated quantitatively by the paper weight technique.

The relative proportion of lipids per unit area of testis decreased 2 and 6 days after exposure, but increased dramatically from 20 to 72 days; by 146 days, it had nearly returned to the normal level.

The relative proportion per unit area of tissue containing phospholipid decreased 2 and 10 days after exposure, steadily rose at 12 days and after until 103 days, and returned to normal at 146 days. The relative proportion of cholesterol increased markedly after 20 days but at 103 and 146 days, it fell to the control level. The significance of these findings is discussed.
\end{abstract}

\section{INTRODUGTION}

Ionizing radiation has been most widely used to produce changes in biological systems, and the testis is one of the few organs studied in the very early stages of research. The effect of X-rays on the germinal epithelium of the testis has been observed by numerous investigators (Bergonié \& Tribondeau, 1906; Kivy, 1951; Shaver, 1953; Oakberg, 1955a, b; Bateman, 1956; Leidl, 1964; Mandl, 1964; Kochar \& Bateman, 1969), but their effect on the interstitial tissue and its production of steroid hormones is limited.

Many workers have investigated the rôle of lipids in the testes. They are reported to be adequate substrates in metabolic processes. Tobeck (1928) and Blumensaat (1929) found lipid in the interstitial cells of human testes. Albert \& Leblond (1949) observed weak coloration with carbonyl reagents in the seminiferous tubules of mice but the interstitial cells were heavily coloured. Lynch \& Scott (1951) detected lipid material in rat Sertoli cells and spermatogonia and considered it to be associated with maturation of spermatogenic cells. They also claimed that the amount of lipid was high in the adult but decreased with increasing age. McEnery \& Nelson (1950) and Long \& Engle 
(1952) located lipids in the human testis in Leydig cells, fibroblast cells and Sertoli cells. Cholesterol was observed in the Leydig cells only. Montagna \& Hamilton (1951) and Montagna (1952) described the presence of lipid material in the tubular epithelium as well as in the interstitial cells. Perlman (1950) found cholesterol in the seminiferous tubules and to a lesser extent in the interstitial cells of the rat testis, though Kunze (1923) and Pollock (1942) described it as present only in the interstitial cells.

Since phospholipid and cholesterol alterations might reflect membrane changes which occur during testicular anomalies, it was decided to undertake a histochemical study of the presence of lipids, phospholipids and cholesterol in the normal mouse testis and the effect on the above substances of exposure of the testis to X-rays.

\section{MATERIAL AND METHODS}

Thirty $A_{2} G$ mature albino mice were used. They were anaesthetized with Nembutal (Abbott Laboratories Ltd) and their testes irradiated with a single dose of $1000 r$ for $7 \mathrm{~min} 41 \mathrm{sec}$. A Westinghouse X-ray. Unit was used for irradiation. Three or four mice were placed in a perspex box with compartments. Only the testes were exposed, the rest of the mouse being covered with a lead shield. The testes were maintained in position by means of a rubber band around the abdomen of the mouse. The box was then placed between the pressed wood and the applicator, the distance between the mice and applicator being $5 \mathrm{~cm}$. The irradiation factors were $240 \mathrm{kV}, 15 \mathrm{~mA}$ and the dose rate was 130 $r / \mathrm{min}$.

Mice were killed at varying intervals between 1 and 146 days postirradiation. The testes were fixed in formol calcium and frozen sections were cut transversely at $10 \mu \mathrm{m}$ from the equator of the testis.

The following histochemical techniques were used:

Lipids: Oil Red $O$ in the supersaturated isopropanol technique (Lillie, 1944), which gave clearer definition than Sudan Black for outlining lipid-coloured areas in irradiated testes.

Phospholipids: The modification by Baker (1946) of the Weigert-SmithDietrich method.

Cholesterol and its esters: the Schultz method.

It is clear that the quantity of lipid in the interstitial tissue varies at different intervals after exposure and, in order to obtain as accurate an estimate as possible, a quantitative study was performed using the paper weight method (Stieve, 1919). The lipid was estimated (in terms of weight of paper) from a standard area of a comparable region of each testis by tracing on paper from photomicrographs of five histological sections at a constant magnification of $\times 165$; after estimating the mean of the readings, the relative proportionate amount per unit area of testis was calculated as:

Weight of paper representing lipid

Total weight of paper 


\section{RESULTS}

\section{Lipids}

In the normal testis, coloration was diffuse in the interstitial tissue and coloured particles could be observed around the luminar region (Pl. 1, Fig. 1). At 2 and 6 days after exposure, the lipid appeared slightly globular in the interstitial tissue and the particles disappeared from the lumen. At 10,16 and 20 days after exposure, the lipid distribution was even more globular with some of the globules scattered within the tubules. At 35 and 48 days after irradiation, though the lipid globules had disappeared from the tubules, they were still present in the interstitial tissue (Pl. 1, Fig. 2). By 146 days, the coloration had again become more diffuse. The relative proportion of lipid per unit area of testis in control mice was $0 \cdot 15$ (Table 1, Text-fig. 1). By 6 days, the amount decreased $(0 \cdot 11)$, rising at 12 days $(0 \cdot 18)$ but again falling at 20 days $(0 \cdot 11)$.

TABLE 1

RELATIVE AMOUNT OF LIPIDS, PHOSPHOLIPIDS AND GHOLESTEROL IN THE TESTIS IN ARBITRARY UNITS

\begin{tabular}{|c|c|c|c|}
\hline $\begin{array}{l}\text { Days post- } \\
\text { irradiation }\end{array}$ & Lipid & Phospholipids & Cholesterol \\
\hline $\begin{array}{c}\text { Control } \\
1 \\
2 \\
6 \\
10 \\
12 \\
16 \\
20 \\
28 \\
35 \\
48 \\
59 \\
72 \\
103 \\
146\end{array}$ & $\begin{array}{l}0.15 \\
0 \cdot 15 \\
0.12 \\
0.11 \\
0.12 \\
0.18 \\
0.08 \\
0 \cdot 11 \\
0.20 \\
0.35 \\
0.34 \\
0.33 \\
0.32 \\
0.22 \\
0.14\end{array}$ & $\begin{array}{l}0.15 \\
\overline{0.10} \\
\overline{0} \\
0 \cdot 10 \\
0 \cdot 16 \\
\overline{0} \\
0.22 \\
0.35 \\
0.34 \\
0.23 \\
= \\
\overline{0} \\
0.19\end{array}$ & $\begin{array}{l}0.10 \\
0.28 \\
0.10 \\
0.09 \\
0.26 \\
0.17 \\
0.15 \\
0.21 \\
0.30 \\
\overrightarrow{0} \\
0.24 \\
0.24 \\
\overrightarrow{0.09} \\
0.08\end{array}$ \\
\hline
\end{tabular}

After this interval, it was always higher than the control value and rose dramatically at 35 days $(0.35)$, remaining at a high peak till 72 days. At 146 days, it had fallen almost to the control level $(0 \cdot 14)$.

\section{Phospholipids}

In the control testis, phospholipid was evenly distributed in the interstitial tissue. There were also phospholipid droplets in the tubules, but mainly in the luminar region (Pl. 1, Fig. 3) identical in position to those shown after application of Oil Red $O$ for lipid. At 2, 10 and 12 days after exposure, the phospholipid was again concentrated in the interstitial tissue, and the spermatozoa showed distinct phospholipid activity. After 12 days, only the interstitial tissue showed phospholipid activity except at 146 days, when slight activity was observed in the luminar region of some tubules. The concentration at different postirradiation intervals varied; in the control testis (Table 1, Text-fig. 1), the 
relative proportion of phospholipid per unit area of testis was $0 \cdot 15$; at 2 and 10 days after exposure, it fell $(0 \cdot 10)$ but at 12 days and after, it steadily rose and at 103 days, it had increased considerably $(0 \cdot 32)$. By 146 days, it had fallen again $(0 \cdot 19)$.

\section{Cholesterol}

Both in the control and irradiated testes, cholesterol was localized entirely in the interstitial tissue. In the control testis, the relative proportion of cholesterol per unit area of testis was $0 \cdot 10$. It rose dramatically $(0 \cdot 28)$ I day after exposure (Table 1, Text-fig. 1), and then fell to the control level at 2 and 6 days. After

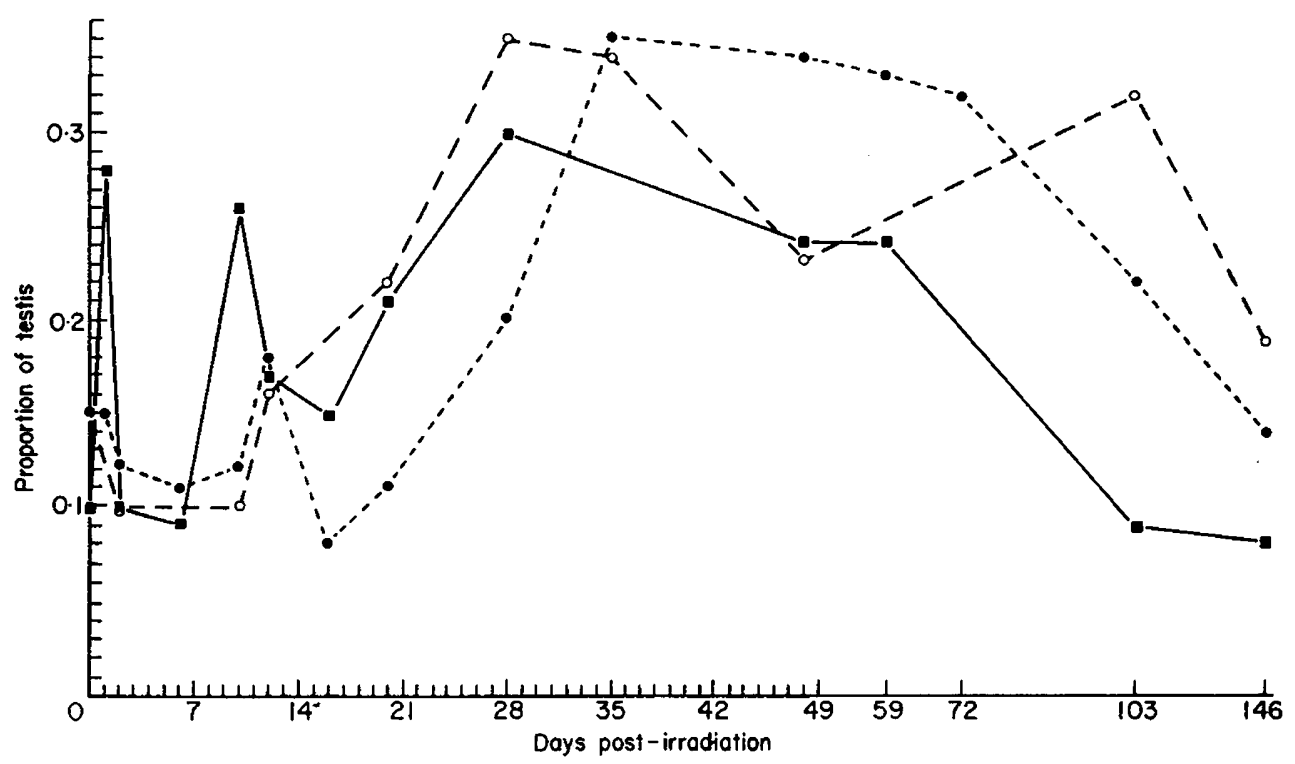

TexT-FIG. 1. The variation in the relative proportions of lipid (O), phospholipid (0) and cholesterol (a) per unit area of testis as shown by the paper weight method in the control testes and in testes at different intervals after irradiation. There is a marked increase in the case of all three substances after 21 days. By 146 days, the concentrations return to nearly normal levels.

this interval, the concentration was higher than the control value and increased $(0 \cdot 30)$ at 28 days, though by 103 and 146 days it had fallen greatly and the concentration was slightly below the control level.

\section{EXPLANATION OF PLATE 1}

FrG. 1. Control testis. The lipids are present mainly in the interstitial tissue and coloured particles are seen around the luminar region in the tubules. $\times 165$.

Fig. 2. Testis 35 days after irradiation. The lipid in the interstitial tissue is very globular and greatly increased. $\times 165$.

FIG. 3. Control testis. Phospholipid is evenly distributed in the interstitial tissue. There are also phospholipid droplets in the tubules and mainly in the luminar region. $\times 195$. 

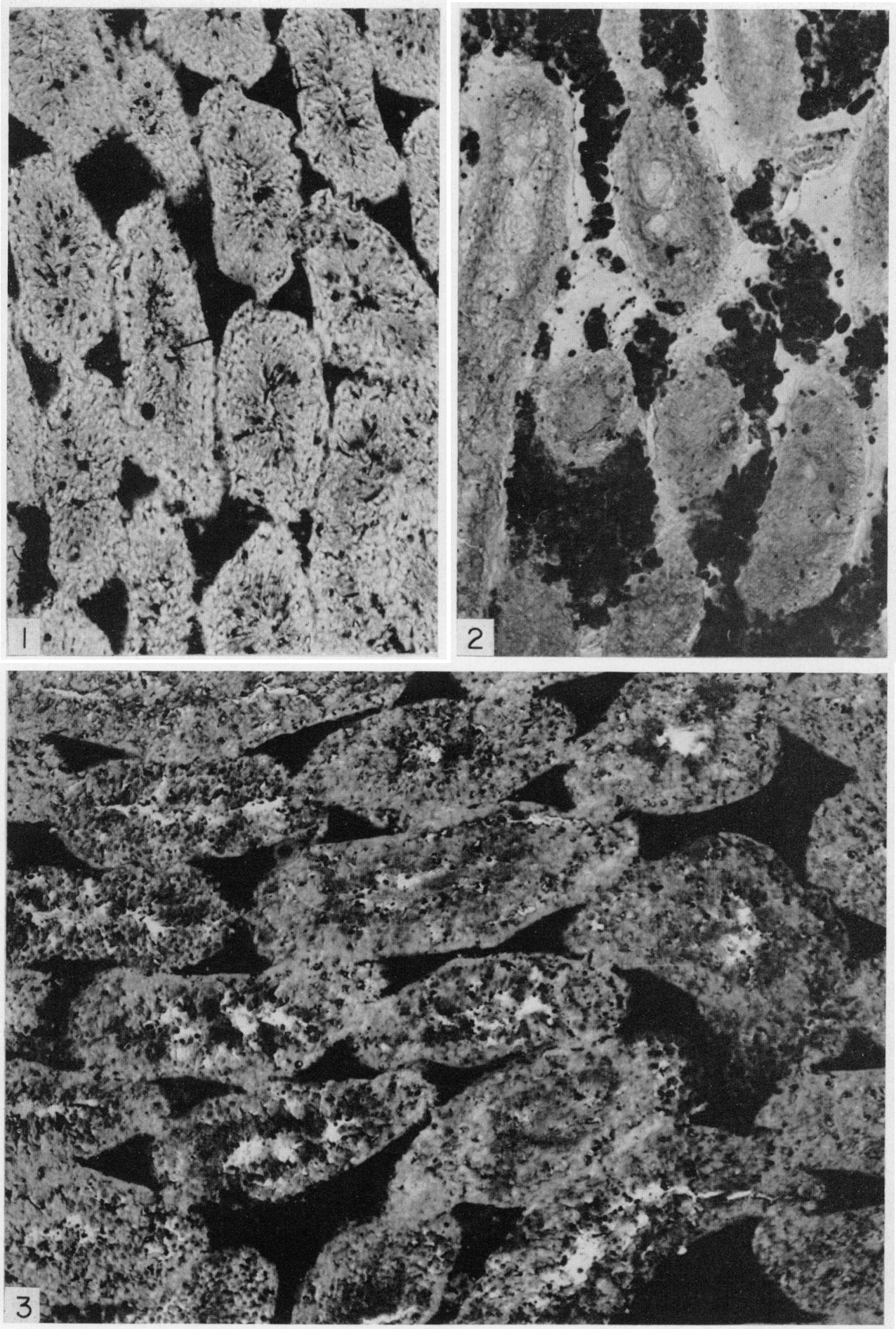

fracine /. 16? 


\section{DISCUSSION}

In the present study of the effect of $\mathrm{X}$-irradiation on the mouse testis, lipids were found mainly in the interstitial cells. The proportion of lipid decreased from 2 to 6 days and at 16 to 20 days after exposure. This is difficult to compare with the effects of other damaging factors, since the majority of investigators have not studied lipid changes over as long a time interval. The initial fall in the present study could be due to breakdown of cell membranes and structures. It is notable that the increase in lipid content commences after 20 days of irradiation when regeneration in the tubules begins, suggesting that the extra lipid in the interstitial tissue may be required for the growth of the germinal cells. Lipids are ideally suited to serve the function of storage and are a main source of energy. The increase could also be due to the fact that since there are fewer germ cells present, there might be less utilization of the lipids. Around 146 days, however, the concentration approximates to that of the control testes (Text-fig. 1). From these results, it is obvious that the changes in lipid produced by X-irradiation are neither constant nor irreversible. This is in marked contrast to the effect of irradiation on testicular enzymes (Kochar \& Harrison, 1971a) since control concentrations of dehydrogenases are never regained after irradiation. The marked increase of lipid seen in the present study has also been reported by other investigators with different testicular disorders. Brack (1923) found that in acute diseases there is hyperplasia of lipid-containing Leydig cells, and that the amount of lipid in interstitial cells depends on its concentration in the blood. Kleinicke (1922) claimed that the increase depended on the severity of damage to the tubular cells and acuteness of the degenerative process. Long \& Engle (1952) found that the amount of lipids in fibrotic human testes was greater than that found in normal testes.

The pattern of phospholipid concentration after irradiation is very similar to that seen in the case of lipids (Text-fig. 1). Davis \& Coniglio (1967) induced cryptorchidism in rat testes, and found that the total amount and concentration of phospholipid were lower in cryptorchid testes 1 month later. The three- to four-fold decrease could be explained by loss of membrane structures which are rich in phospholipids. The proportionate increase of phospholipids in the present study occurs as soon as regeneration of the tubules starts, showing that this might be due to a resurgence of spermatogenesis. Dawson (1957) claims that 'this type of synthesis may vary considerably and its rate may be in excess of that required for the normal turnover of structural elements'. There is certainly a marked increase in the vascularization of the testis once regeneration occurs (Kochar \& Harrison, 1971b). Mancini, de la Balze, Scarpa, Lobo \& Andrade (1954) found that an increased proportion of lipids and phospholipids was associated with decreased proportions of tubular elements or increasing proportions of interstitial tissue. The site of $\beta$-glucuronidase activity also moves from the tubules to the Leydig cells after regeneration (Kochar \& Harrison, 1971a).

Since cholesterol serves as a raw material in the formation of important hormonal substances, and is the main substrate for androgen biosynthesis (Dorfman, Forchielli \& Gut, 1963), the level of androgen secretion is governed 
by a preceding accumulation of cholesterol. Pollock (1942) found cholesterol in the interstitial cells of guinea-pigs, mice and rabbits and suggested a relationship to testosterone content. Ichihara (1969) found cholesterol both biochemically and histochemically in the interstitial cells of mice aged from 5 to 63 days and found that it increased actively from 42 to 49 days.

In the present study, cholesterol was found only in the interstitial cells. It increased proportionately 1 day after exposure, decreased to nearly normal levels by the 6th day and finally again increased after 6 days. Only at 106 and 146 days did it fall to a level slightly lower than normal. Perlman (1950) found that the amount of cholesterol was reduced in the cryptorchid testis in comparison to control rats, 20 days after operation. Davis \& Coniglio (1967) found an increase in the concentration of cholesterol after 1 month of cryptorchidism, but there was no increase in the total amount of cholesterol. This could be due to the accumulation of cholesterol as the germinal epithelium atrophied. The present investigation has, however, shown an increase of cholesterol not only at the time of atrophy but also during the regenerative process; though it returns to nearly normal levels after regeneration has considerably advanced. From the work of Hanes (1911) and Nelson (1934), it is thought that the testis is capable of secreting androgen so long as the interstitial cells are intact, though the germinal cells may be absent or destroyed. Abbot (1959) reported that there were no changes in the secretory capacity of the testis after X-irradiation, but Gunn, Gould \& Anderson (1960) showed that testosterone could prevent atrophic changes in tubules caused by $\mathrm{X}$-irradiation. In addition to this conflicting data, Ellis \& Berliner (1963) concluded that androgen production by the testis could be altered after total body irradiation. As it is known that Leydig cells secrete testosterone, it would appear that they are radiosensitive since they manifest histochemical changes due either to a direct effect of X-rays on the cells, or to disturbance of gonadotrophin secretion.

\section{AGKNOWLEDGMENTS}

The help of Mr D. J. Kidd and Mr A. Brooks in preparing the illustrations, and Mr L. G. Cooper, Mr E. Joughin and Mr J. M. Rice in technical advice and assistance is very gratefully acknowledged. We also wish to extend our thanks to Dr T. A. Chalmers and Miss B. O'Donnell, for providing the facilities to irradiate the mice.

The research was performed during the tenure of a John Rankin Fellowship in Anatomy of the University of Liverpool by Dr N. K. Kochar.

\section{REFERENCES}

Аввот, C. R. (1959) The effect of X-irradiation on the secretory capacity of the testes. F. Endocr. 19, 33. Albert, S. \& Leblond, G. P. (1949) Age changes revealed by carbonyl reagents in tissue sections. F. Anat. 83, 183.

BAKER, J. R. (1946) The histochemical recognition of lipine. Q. Fl microsc. Sci. 87, 441.

Bateman, A. J. (1956) Sensitivity of immature mouse sperm to the mutagenic effects of X-rays. Nature, Lond. 178, 1278.

Bergonit, J. \& Trrbondeau, L. (1906) Actions des rayons X sur le testicule. C.r. Séanc. Soc. Biol. 14, 911.

BlumensaAt, C. (1929) Lipoid-und Eisenablagerungen in Nebennieren und Hoden bei Knaben vom 1 bis 15 Lebensjahr. Virchows Arch. path. Anat. Physiol, 271, 639. 
Brack, E. (1923) Zur pathologischen Anatomie der Leydigzelle. Virchows Arch. path. Anat. Physiol. $240,127$.

Davis, J. T. \& Coniglio, J. G. (1967) The effect of cryptorchidism, cadmium and antispermatogenic drugs on fatty acid composition of rat testis. J. Reprod. Fert. 14, 407.

Dawson, R. M. C. (1957) The animal phospholipids: their structure, metabolism and biological significance. Biol. Rev. 32, 188.

Dorfman, R. I. E., Forghielli, E. \& Gut, M. (1963) Androgen biosynthesis and related studies. Recent Prog. Horm. Res. 19, 251.

Ellis, Le G. C. \& Beruner, D. L. (1963) The effect of ionising radiations on endocrine cells. 1. Steroid biotransformations and androgen production by testes from irradiated mice. Radiat. Res. 20, 549 .

Gunn, S. A., Gould, G. T. \& Anderson, A. D. (1960) The effect of X-irradiation on the morphology and function of the rat testis. Am. F. Path. 37, 203.

HANEs, F. M. (1911) The relation of the interstitial cells of Leydig to the production of an internal secretion by the mammalian testis. F. exp. Med. 13, 338.

IchinARA, I. (1969) Cholesterol changes in developing testicular cells of the mouse. Histochemical and biochemical study. Anat. Rec. 163, 595.

Krvy, E. (1951) The immediate and prolonged effect of single dose $\mathbf{X}$-irradiation on the testis and germinal epithelium of the golden hamster (Cricetus auratus). F. Morph. 88, 573.

Kreinicke, K. (1922) Der Lipoidstoffwechsel der mannlichen Keimdrusen. Frankf. Z. Path. 27, 185.

Kochar, N. K. \& Bateman, A. J. (1969) Post-irradiation changes in Sertoli cells. F. Reprod. Fert. 18, 265.

Kochar, N. K. \& Harrison, R. G. (1971a) The effect of X-rays on enzymes of the mouse testis. $\mathcal{F}$. Anat. 109, 39.

Kochar, N. K. \& Harrison, R. G. (1971b) The effect of X-rays on the vascularization of the mouse testis. Fert. Steril. 22, 53.

Kunze, A. (1923) Über Zwischenzellentumoren im Hoden des Hundes. Virchows Arch. path. Anat. Physiol. 240, 144.

LEIDL. L. W. (1964) Degeneration und Regeneration des Keimepithels beim Bullen nach Röntgenbestrahlung. Dt-öst. tierärztl. Wschr. 15, 670.

Licuid, R. D. (1944) Various oil soluble dyes as fat stains in the supersaturated isopropanol technic. Stain. Technol. 19, 55.

Long, M. E. \& Engle, E. T. (1952) Cytochemistry of the human testis. Ann. N.Y. Acad. Sci. 55, 618.

LyNch, K. M. \& ScotT, W. W. (1951) Lipid distribution in the Sertoli cell and Leydig cell of the rat testis as related to experimental alterations of the pituitary gonad system. Endocrinology, 49, 8.

Mancini, R. E., de la Balze, F. A., Scarpa, C. J., Lobo, R. \& Andrade, J. (1954) Histologic study of testes at puberty. II. Histochemistry. F. clin. Endocr. Metab. 14, 818.

MANDL, A. M. (1964) The radiosensitivity of germ cells. Biol. Rev. 39, 288.

MaEnery, W. B. \& Neison, W. O. (1950) Cytochemical studies on testicular lipids. Anat. Rec. 106, 221.

Montagna, W. (1952) The distribution of lipids, glycogen and phosphatases in the human testis. Fert. Steril. 3, 27.

Montagna, W. \& Hamilon, J. B. (1951) Histological studies on human testes. 1. The distribution of lipids. Anat. Rec. 109, 635.

NeLson, W. O. (1934) Effect of gonadotrophic hormone injections upon hypophyses and sex accessories of experimental cryptorchid rats. Proc. Soc. exp. Biol. Med. 31, 1192.

OAKBERG, E. F. (1955a) Sensitivity and time of degeneration of spermatogenic cells irradiated in various stages of maturation in the mouse. Radiat. Res. 2, 369.

OAKberg, E. F. (1955b) Degeneration of spermatogonia of the mouse following exposure to X-rays, and stages in the mitotic cycle at which cell death occurs. 7. Morph. 97, 39.

Perlman, P. L. (1950) The functional significance of testis cholesterol in the rat. Histochemical observations on the testes following hypophysectomy and experimental cryptorchidism. Endocrinology, 46, 341 .

Pollock, W. F. (1942) Histochemical studies of the interstitial cells of the testes. Anat. Rec. 84, 23.

SHAVER, S. L. (1953) X-irradiation injury and repair in the germinal epithelium of male rats. Injury and repair in adult rats. Am. F. Anat. 92, 391.

Streve, H. (1919) Das Verhaltnis der Zwischenzellen zum generativen Anteil im Hoden der Dohle (Colaeus monedula). Arch. EntwMech. Org. 45, 455.

Tовеск, A. (1928) Uber die Lipoid-und Eisenablagerungen in Nebennieren und Hoden in Sauglingsalter. Virchows Arch. path. Anat. Physiol. 267, 690. 